\title{
State-Level Renewable Energy Policy Implementation: How and Why Do Stakeholders Participate?
}

\author{
Valerie Rountree ${ }^{1 *}$ and Elizabeth Baldwin ${ }^{2}$ \\ 'School of Natural Resources and the Environment, University of Arizona, Tucson, AZ, United States, ${ }^{2}$ School of \\ Government and Public Policy, University of Arizona, Tucson, AZ, United States
}

For most of the twentieth century, large-scale, utility-owned power plants dominated electricity generation in the United States. Today, however, a growing share of electricity comes from renewable energy sources such as solar and wind energy, which are often small-scale and distributed. In the absence of significant national policies, the Renewable Portfolio Standard has emerged as the key state-level policy governing the deployment and use of renewable energy sources. While renewable energy offers new possibilities for clean energy generation, it also poses new regulatory and governance challenges as a wide range of stakeholders, such as the utilities, regulatory agencies, environmental and consumer advocacy groups, electricity generators, and private citizens, increasingly seek to influence how Renewable Portfolio Standards are implemented. In this study,

OPEN ACCESS

Edited by: Leah Sprain, University of Colorado Boulder, United States

Reviewed by:

Amanda Buday,

Fort Hays State University, United States Justin Reedy,

University of Oklahoma, United States

*Correspondence: Valerie Rountree vrountree@email.arizona.edu

Specialty section: This article was submitted to Science and Environmental Communication,

a section of the journal Frontiers in Communication

Received: 31 October 2017 Accepted: 18 January 2018 Published: 07 February 2018

Citation:

Rountree V and Baldwin E (2018) State-Level Renewable Energy Policy Implementation: How and Why Do

Stakeholders Participate? Front. Commun. 3:6.

doi: 10.3389/fcomm.2018.00006 we ask how and why do stakeholders participate in decision-making about how these policies are implemented? Given the unique context of renewable energy policy, the longterm and iterative nature of renewable energy policy implementation, and the wide range of actors involved, we look at the suite of participatory opportunities available to stakeholders. We interview stakeholders in two states - Colorado and Nevada - to identify the mechanisms through which stakeholders participate and the incentives (or disincentives) that influence their willingness to do so. We find that while decision makers in both the states use a variety of mechanisms to engage stakeholders in decision-making, meaningful participation may be limited to stakeholder groups that are knowledgeable about the issues, have the resources to engage in long-term and sustained participation, and have long-standing relationships with decision makers and other stakeholders. Although many stakeholders participate in multiple types of processes to achieve a broader range of benefits, they often perceive their participation as superficial; and yet, their continued participation suggests that they may play a long game, building coalitions, relationships, and knowledge to position themselves to influence decisions later on. Finally, we find that the regulatory environment influences which participatory processes are available, the incentives for participation, and ultimately the outcomes of stakeholder participation.

Keywords: Renewable Portfolio Standard, renewable energy, stakeholder participation, policy implementation, energy democracy

\section{INTRODUCTION}

For most of the twentieth century, large-scale, fossil-fuel powered, utility-owned power plants dominated electricity generation in the United States. In recent decades, however, the electric sector has experienced a momentous shift toward renewable energy resources for electricity generation. For example, the share of electricity generated from wind and solar increased from two-tenths of $1 \%$ 
in 2000 (Fleischmann, 2016) to 7\% in 2016 [Energy Information Administration (EIA), 2017]. These new generation facilities are often small-scale and distributed (Martin, 2009), which has disrupted the centralized nature of electricity generation (Bakke, 2016) and opened up the sector to participation by a new and diverse set of actors.

In the United States, policies that govern the use of renewable energy for electricity generation have been almost entirely left to individual states (Lutsey and Sperling, 2008). In particular, many states have adopted Renewable Portfolio Standards (RPSs), which require that a minimum percentage of electricity sold by utilities must come from eligible renewable energy resources. RPSs vary by state in terms of the percent of energy required from renewables, the type of renewables allowed, the date by which these goals must be achieved, and the consequences-if any - for non-compliance. In some cases, the requirement applies only to investor-owned utilities, which are regulated by state Public Utilities Commissions (PUCs). In other states, however, RPSs extend to include municipalities and electric cooperatives, albeit often with lower requirements. As of January 2016, 29 states, Washington D.C., and 2 territories had adopted an RPS, and 8 additional states had set other renewable energy goals (Durkay, 2017).

Our focus in this study is on participatory opportunities in RPS policy implementation for stakeholders who may, for example, be involved in, electricity rate changes, and the design of renewable energy and energy efficiency programs for customers. Increased involvement of stakeholders in electric sector decisionsalso known as "distributed governance" (Baldwin et al., 2018) stems from the idea that the transition away from a centralized, fossil fuel paradigm to a decentralized, renewable energy paradigm is both technically challenging and has the potential to drastically change the sector's winners and losers. In this setting, stakeholders have an important role in shaping decisions about how to carry out complex policies like the RPS.

However, the culture of decision-making in the electric sector, which comprises a network of business interests, stakeholders, and legal structures, is proving difficult to change (Bakke, 2016). Electric utilities, while obligated to serve their customers, have little economic incentive to share the market or decision-making power with other stakeholder groups. PUCs in many states have strong ties with utilities (Lifsher, 2015) and may therefore be reticent to act in ways that could damage this relationship. As Bakke (2016) points out, transforming the grid does not just entail introducing new technologies, but is also a cultural system and "the stakeholders - utilities, investment firms, power plant owners, mining firms, and "too-big-to-fail" multinational conglomerates-will not go gently into the future's bright night" (Bakke, 2016, p xviii).

Growing research identifies a number of potential benefits to stakeholders' participation, such as improved decisions, decreased decision-related costs, fewer delays in decision implementation, and greater stakeholder support for decisions (Beierle and Konisky, 2000; Cotton and Devine-Wright, 2012). And yet, many empirical studies of participatory processes suggest that these benefits are rarely realized, and that all too often participatory processes can be a box-checking exercise rather than a meaningful effort to engage stakeholders in the policy process. In the context of renewable energy policy, we know little about how and why stakeholders participate in electric sector decision-making, or about how agency rules and procedures shape their incentives to do so. To address this gap, we ask how and why do stakeholders participate in decisions about RPS implementation? Using interview data from two states-Colorado and Nevada-we identify the mechanisms through which stakeholders participate and the incentives that influence their willingness to do so. First, we find that stakeholders may play a long game, participating in the short-term to build coalitions, relationships with decision makers, and knowledge that will eventually allow them to influence decisions later on; second, stakeholders often participate in multiple types of processes to achieve goals; and third, the regulatory environment influences which participatory processes are available, the incentives for participation, and ultimately the outcomes of stakeholders' participation.

We begin with a brief overview of the process and key actors involved in the implementation of RPS policies. Next, we explore the scholarly literature on stakeholders' participation and discuss the benefits and drawbacks to participation, the mechanisms through which stakeholders participate in renewable energy and other natural resource contexts, and the incentives that affect their willingness to participate.

\section{BACKGROUND}

The implementation of RPSs can be broken down into a series of stages, beginning with policy adoption. Electric utilities translate RPS objectives into plans with concrete, measurable actions, for example, increasing renewable energy capacity with new generation facilities, entering into contracts with existing renewable energy producers, or creating customer programs to increase energy efficiency. Such plans are subject to approval by electricity regulators - the Public Utilities Commissions (PUCs) (Berry and Jaccard, 2001). Utilities thus shape whether, when, and how RPSs are implemented, and the extent to which RPS goals are achieved. In this study, we focus on implementation by investor-owned utilities for two reasons: (1) investor-owned utilities service the majority of electricity customers in both Colorado and Nevada and (2) unlike municipal and cooperative utilities, investor-owned utilities are regulated by PUCs and thus are more tightly bound to RPS policy requirements and to state laws regarding public engagement. From here on they are simply referred to as "utilities."

Stakeholders are increasingly involved in decisions related to RPS implementation (Scott, 2015; Ulibarri, 2015). We define stakeholder broadly as any person or group who affects or is affected by the actions of utilities and PUCs (Freeman and Reed, 1983 , p. 91). We differentiate these groups as decision-making stakeholders ("decision makers"), which include utilities and PUCs, and non-decision-making stakeholders ("stakeholders"), which include electricity customers, consumer advocacy groups, environmental organizations, electricity generators, private citizens, and the renewable energy technology industry.

Many states have developed formal and informal opportunities for stakeholders to participate in electric sector 
decision-making (Baldwin et al., 2018). At a minimum, thanks to the Administrative Procedures Act of 1946 and its state analogs, federal and state agencies-PUCs included-are required to hold open meetings whenever they adopt new rules (Rosenbloom, 1983; West, 2004; Crow et al., 2016). Stakeholders' participation is also common in legal proceedings such as rate-setting cases. Legal proceedings are typically initiated when utilities propose a rate increase or other regulatory change from the PUC. The PUC then acts as fact finder and judge in a legal proceeding that culminates in approval (or disapproval) of utility requests. Stakeholders may intervene in these proceedings and contribute information to the administrative record. Historically, this was the predominant mechanism through which stakeholders could voice their opinions to PUCs (Gormley, 1983; Baldwin et al., 2018), but a number of other mechanisms now exist, although these have largely been unexplored in the context of renewable energy or the electric sector.

Despite the legal requirements to allow stakeholder comments, there is no mandate that stakeholders' participation be meaningful, which we define here as stakeholder inputs that inform or shape PUC or utility decisions. Given that utilities have interests that may not align with those of other stakeholder groups, they may be resistant to sharing decision-making power. Further, the close ties between PUCs and utilities may bias regulators' decisions in some cases (Lifsher, 2015).

Public responses to renewable energy and associated policies are understandably varied and complicated. While many people want more choice in energy sources, others are concerned about the location of renewable energy generation sites and the added cost, which is sometimes distributed across the broader customer base. Given the value-laden decisions inherent in renewable energy and other environmental issues, scholars widely note the importance of stakeholders' participation in agency decisionmaking, arguing that, when done well, stakeholder input can improve the legitimacy and quality of decisions. Conversely, however, a lack of participation can contribute to opposition to the decision and distrust in decision makers (Nabatchi and Leighninger, 2015).

\section{LITERATURE REVIEW}

The theory and practice of participation are founded on the idea that particularly complex or "wicked" problems, such as those often encountered in the public-environment arena, are better addressed by multiple actors than by single agencies (McGuire, 2006). Increasingly, scholars, practitioners, and citizens are recognizing the value of stakeholders' participation in government decision-making. Stakeholders' participation may lead to improved democratic accountability and decisions, and the participatory process itself has additional benefits that may help to build trust and enhance problem-solving in future situations. However, there are also potential drawbacks to participation that may make it unsuitable for certain policy situations: stakeholders' involvement may reduce the quality or perceived quality of the decision, be costly, and, if not conducted properly, may backfire or create a false sense of legitimacy in the decision. We explore each of these in greater detail below. We then turn to the mechanisms and incentives for participation described in the literature.

\section{Potential Benefits of Stakeholders' Participation}

Participation is a means of allowing private individuals and groups to influence the decisions that affect them (Cogan and Sharpe, 1986; Fung, 2006) and is often considered foundational to democratic ideals (Perhac, 1998; Bryson et al., 2013). By participating in decision-making, stakeholders are better able to hold elected and unelected officials accountable to laws and their constituents, which also promotes transparency in government decisions (West, 2004).

The outcomes of participatory processes, that is, the decisions themselves, may be improved in terms of quality, perceived legitimacy (Cogan and Sharpe, 1986; Wondolleck and Yaffee, 2000), stakeholder buy-in (Chess and Purcell, 1999), transparency (Reed, 2008; Dyer et al., 2014), timeliness (Cogan and Sharpe, 1986), and equity (Simonsen and Robbins, 2000), particularly when stakeholders are involved early on in decision-making and when processes are intensive and deliberative (Beierle, 2002; Blackstock et al., 2007; Teitelbaum, 2014). Stakeholders can provide local knowledge, information, ideas, and opinions that can inform project design and allow interventions and technologies to be better adapted to local conditions (Cogan and Sharpe, 1986; Renn et al., 1993), which may lead to decisions that are more durable because they are based on more complete information (Beierle, 2002; Koontz and Thomas, 2006).

Fair, transparent, and equitable participatory processes have the potential to produce long-lasting benefits (Nabatchi, 2010; Boyte, 2011), which may carry over into future planning efforts (Cogan and Sharpe, 1986; Reed, 2008). In particular, such processes may allow participants to generate and share knowledge about the issue (Burroughs, 1999; Feldman and Quick, 2009), which may empower stakeholders to participate in future activities (Macnaghten and Jacobs, 1997) and increase public awareness of the issue (Bryson et al., 2013); build social capital, develop trust, and resolve conflict (Blackstock et al., 2007; Dyer et al., 2014; Teitelbaum, 2014); and develop mutual understanding (Renn et al., 1993; Fung, 2007).

\section{Potential Drawbacks of Stakeholders' Participation}

The time and financial costs associated with stakeholders' participation can be significant, particularly in intensive and deliberative activities, and are incurred by both decision makers and stakeholders (Irvin and Stansbury, 2004; Nabatchi and Leighninger, 2015). Such costs can delay action (Bojórquez-Tapia et al., 2004) and divert resources away from carrying out the actual decision (Irvin and Stansbury, 2004), and lead to "consultation fatigue" among participants (Wondolleck and Yaffee, 2000; Burton et al., 2004). These costs may lead some agencies to exclude certain stakeholder groups, minimize participation, or eliminate it entirely from planning efforts (Cogan and Sharpe, 1986).

Stakeholders' participation does not always lead to improved decisions (Irvin and Stansbury, 2004), particularly when 
processes involve insufficient deliberation among participants (Beierle, 2002). The credibility of decisions may be questioned when stakeholders lack sufficient expertise to meaningfully contribute to technical debates (Pearce and Pearce, 2010), leading some decision makers to ignore stakeholder input or exclude stakeholders from future planning efforts (Beierle, 2002). For example, decisions of a technical nature-such as those related to renewable energy and the electric sector more broadly-have often been viewed as best left in the hands of "experts" (DeSario and Langton, 1987) because non-expert stakeholders may not adequately understand the issue, technology, or potential risks involved (Perhac, 1998). Walker and Daniels (2001) point out this increasingly salient paradox: stakeholders want to influence decision-making, but also want decisions to be based on the best possible scientific information.

Decision makers may also do a poor job of conducting participatory processes, either intentionally because they perceive little value in stakeholder input (Lee et al., 2015), or unintentionally because of resource limitations (Lukensmeyer et al., 2011). When processes are poorly conducted-as the majority are (Levine et al., 2005) - they may be counterproductive (Nelkin and Pollak, 1979). One study found that officials usually had their minds made up prior to public meetings (Adams, 2004); in turn, this creates a false sense of legitimacy in the decision and distrust by stakeholders in the participatory process (Lee et al., 2015). If stakeholders perceive that their input is ignored, they may view their participation-and any future attempts-as pointless, which can lead to even greater hostility toward decision makers (Irvin and Stansbury, 2004) and "reinforce their suspicions of ordinary politics and ineffectual bureaucracies" (Lee, 2014, pp. 7). Effective participatory processes require skilled facilitation (Holmes, 2011); however, many of the staff working with public groups lack the knowledge and skills necessary to effectively facilitate participatory processes (Lukensmeyer et al., 2011) and are often the youngest and least experienced employees in the agency (Nabatchi and Leighninger, 2015).

Other concerns regarding stakeholders' participation relate to representation and power dynamics, that is, who is allowed to participate, the extent to which they influence decisions, and how the balance of power influences these (Quick and Bryson, 2016). Exclusion and equality remain concerns of participatory processes (Quick and Bryson, 2016) as some processes may reinforce existing power imbalances by discouraging minority representation (Dasgupta and Beard, 2007; Crow et al., 2016) or may be particularly difficult for lay stakeholders to navigate (Endres, 2009). Participation more broadly may encourage those involved to become overly focused on short-term actions while ignoring the bigger picture (Lee et al., 2015).

\section{Mechanisms for Stakeholders' Participation}

Stakeholders' participation occurs through a variety of mechanisms that vary in intensity. Arnstein's (Arnstein, 1969) "ladder of participation" was an early vision of participation as a hierarchy, where lower-rung processes involve information provision and sharing, while higher-rung processes allow citizen control of decisions and may involve collaborations, partnerships, or co-management (Arnstein, 1969). While low-intensity (or lowerrung) processes provide limited opportunities for stakeholders to influence policy, more intensive (higher-rung) activities allow information and opinion exchange with the possibility of dialog between participants. However, information exchange alone has limited "democratizing potential" because there is limited opportunity for learning to take place and because decision makers are typically not required to factor stakeholder input into their decisions [European Institute for Public Participation (EIPP), 2009].

The most intensive-and arguably most meaningfulparticipatory mechanisms are those that include deliberation, which Nabatchi and Leighninger (2015) defined as the "thoughtful, open and accessible discussion about information, views, experiences, and ideas during which people seek to make a decision or judgments based on facts, data, values, emotions, and other less technical considerations" ( $p$ 15). Rather than simply exchanging information, deliberation allows for the possibility of opinions to be changed, participants to come to a shared understanding of the issues and potential solutions [European Institute for Public Participation (EIPP), 2009], and the development of mutual understanding (Roberts, 2004). Such activities may include workshops, advisory committees, and taskforces, although no single process is best suited to all circumstances (Fung, 2006; Tippett et al., 2007).

The specific participatory process used to engage stakeholders depends on a number of contextual factors (Rowe and Frewer, 2000), which may include the goals of the process, that is, whether stakeholders' participation is seen as an end in itself or as a means to an end (Wiedemann and Femers, 1993); who the process is targeted toward (e.g., the general public, a specific subset of the public or key stakeholder groups) (Quick and Bryson, 2016); the history of cooperation or conflict among stakeholder groups and decision makers; and the technical or social complexity of the issue (Bryson et al., 2013). The process chosen and the way it is conducted often indicate whether authorities have a genuine interest in implementing any stakeholders' recommendations or whether the process is merely meant to placate stakeholders (Rowe and Frewer, 2000).

\section{Incentives for Participation}

In response to the growing desire by stakeholders to have a say in decisions, laws and regulations have been developed that allow citizens to monitor, comment, or otherwise weigh-in on government policies and decisions (Nabatchi and Leighninger, 2015). Even so, it is up to stakeholders to volunteer their participation and up to agency staff to invest time and energy in facilitating participatory processes. Therefore, it is important to understand why and under what circumstances stakeholders and agencies may choose to engage with each other, as these incentives impact whether stakeholders are willing to participate and whether the goals for participation are achieved (Ansell and Gash, 2008).

Stakeholders may be more likely to participate when they view participation as a necessary means of achieving their goals (Ansell and Gash, 2008); there are opportunities for knowledge sharing (Burroughs, 1999); and when they perceive that their involvement will impact decisions, that is, the process will be meaningful (Bradford, 1998; Martin et al., 1999; Brown, 2002; Geoghegan and 
Renard, 2002; Schneider et al., 2003; Warner, 2006). Stakeholders may be less likely to participate when there are significant power differences between their group and the decision makers, or among stakeholder groups (Burroughs, 1999); they have little knowledge or understanding of the issue (Martin et al., 1999); the mechanism for participation is misaligned with cultural or social norms (Wondolleck et al., 1996); the costs of participating are high compared to perceived benefits (Wondolleck et al., 1996); and when they perceive that their involvement is superficial and aimed at appeasement (Futrell, 2003). If stakeholders think their needs are better met in the courts or legislative branches, they may forgo working with agencies on policy implementation (Ansell and Gash, 2008).

The history of cooperation between agency and stakeholders and the specific context of the issue can also affect willingness of stakeholders to participate. A history of conflict, for example, leads to low levels of trust and low commitment to cooperate by all parties, whereas successful participation in the past leads to higher trust and social capital among participants and more collaboration in the future (Chess and Purcell, 1999). When stakeholders hold opposing interests, they may find that none can achieve their goals without working together (Futrell, 2003; Ansell and Gash, 2008).

Although our focus is on incentives for stakeholders, it is important to acknowledge that there are also incentives and disincentives for decision makers to engage stakeholders, which affect whether and how they choose to do so. Agency administrators and other decision makers may be less motivated to engage stakeholders and share decision-making power if they feel decisions are best left to the "experts," if outcomes of participation seem unpredictable (Burroughs, 1999), or if they have limited resources (Nabatchi and Leighninger, 2015). Decision makers and agencies may also choose not to allow stakeholders' participation if they are not required to do so, stakeholders have diverse goals that cannot all be accommodated, stakeholders lack motivation or are unable to engage with decision makers, or when opposition to the policy or plan is overrepresented among stakeholders (Cotton and Devine-Wright, 2012).

In our exploration of how and why stakeholders participate in decision-making about RPS implementation, we look critically at the types of mechanisms, the incentives for stakeholders to participate in each, and the connections between the broader regulatory environment and outcomes of stakeholders' involvement. Although the existing literature on stakeholders' participation offers important insights, much of it comes from contexts others than renewable energy or electric-sector governance. Moreover, many of these studies focus on single mechanism of participation, such as public meetings, and may overlook potentially important avenues of participation for lay stakeholders (private citizens and utility customers), or fail to recognize how multiple individual mechanisms create an entire suite of opportunities for stakeholders to influence policy. Given the unique context of renewable energy policy, the long-term and iterative nature of RPS implementation and policy modification, and the wide range of stakeholders involved, in this study we consider the suite of participatory opportunities available to stakeholders, asking how and why stakeholders participate in the RPS policy arena.

\section{DATA COLLECTION AND ANALYSIS}

In this study, we ask (1) how do stakeholders participate in decision-making related to renewable energy policy implementation, and (2) what incentives or disincentives affect stakeholders' participation in this context. To answer these questions, we use a qualitative analysis of key-informant interviews conducted in Colorado and Nevada in June 2016. These two states were selected because, although both states have RPS policies that have been in place for many years, they have different histories of RPS adoption, modification, and implementation. The RPS is salient to voters in both states, and yet each state uses different approaches to stakeholders' engagement, which allows us to see a range of approaches. However, we acknowledge that participatory mechanisms and incentives may vary in states with less or different renewable energy capacity, or with different histories of cooperation and conflict between electric utilities, regulators, and other stakeholder groups.

Stakeholders were identified through (1) a review of regulatory and renewable energy policy websites that identified stakeholder groups involved in policy development and implementation, (2) a review of recent legal proceedings related to renewable energy to identify intervening parties, and (3) snowball sampling. Although these methods may not have identified all groups involved or all processes by which stakeholders participate, through snowball sampling, we tended to hear about the same individuals, groups, and processes, suggesting that we had an adequate sample and captured the range of mechanisms.

Stakeholders and decision makers representing a broad range of interests were invited to participate in interviews. Specifically, we invited representatives from utilities, PUCs, environmental organizations, consumer advocacy groups, other government agencies, community groups, and individuals representing various public interests. Although we focus on the incentives for stakeholders to participate in decision-making, we also interviewed decision makers to gain a more robust understanding of the state context and to hear their perspectives on why and how stakeholders are involved in decision-making. Because our focus was on processes directly connected to policy and decision-making, we were most interested in "expert stakeholders" who participate regularly and understand both the formal and informal mechanisms through which participation occurs. In total, we conducted 9 interviews in Nevada (1 with decision makers and 8 with stakeholders) and 11 interviews in Colorado ( 2 with decision makers and 9 with stakeholders), each ranging from $45 \mathrm{~min}$ to $2 \mathrm{~h}$, depending on the availability of interviewees. Most of our interview sessions included multiple members of the organization.

Interview participants were asked open-ended questions about the following: the ways they participate in renewable energy policy development and implementation; how they work with utilities and/or the PUC to implement these policies or, when talking with decision makers, how they engage other stakeholders in these activities; why they participate or seek stakeholders' participation in these particular processes; and what they see as the benefits and drawbacks associated with each process. Because we did not prompt interviewees with a list of all possible participatory 
processes, it is likely that there are additional avenues through which stakeholders participate in renewable energy policy implementation that we did not hear about; however, by allowing interview participants to discuss whatever aspects of the participatory processes they thought were most relevant and important, we believe that we captured the most important processes and avoided imposing our own biases toward specific mechanisms.

Written notes were taken during each interview by one or both researchers and transcribed into NVivo software for content analysis, where the data on mechanisms and incentives for participation were coded and qualitatively analyzed based on the following themes: descriptions of participatory processes; who is involved; when are they involved (in the decision-making process); why are they involved; barriers to participation; interactions between stakeholder groups; and stakeholders' conflict.

Unless otherwise specified, all information in the "state context" and "results" sections were provided by interviewees. To comport with institutional review protocols, we avoid revealing identifying information.

\section{RESULTS}

\section{State Context}

Interviewees indicated that the social, economic, and political contexts, as well as the availability of fossil fuel and renewable energy resources in Colorado and Nevada, played a significant role in how and why RPSs were adopted in each state, as well as how stakeholders and decision makers work together to design effective implementation plans. Although the specific stakeholder groups vary between the two states, the type of groups involved in RPS implementation are the same and include utilities, PUCs, environmental advocacy groups, consumer advocacy groups, utility customers, electricity generators, and the renewable energy technology industry. Following is a brief overview of the context of each state.

\section{Colorado}

In 2004, Colorado voters passed the nation's first voter-led RPS (called the Renewable Energy Standard in Colorado). Similar legislation had failed to pass four times in the legislature, a failure that interviewees attributed to strong opposition from electric utilities, who tend to oppose any kind of mandate that forces change. Since then, the state's largest utility, Xcel, has become a leading advocate for further increases to the RPS for several reasons, including customer support for renewable energy, costcompetitiveness of wind energy with other technologies, and the wide perception that the RPS is a key driver of decreased renewable energy costs. Since 2004, the legislature has increased the amount of renewable energy required three times. The RPS now requires that investor-owned utilities procure at least $30 \%$ of electricity from renewable resources by $2020,3 \%$ of which must come from distributed resources such as rooftop solar. Municipalities and cooperatives are subject to a lesser $20 \%$ standard (Renewable Energy Standard, 2017). Requirements increase incrementally until these goals are reached. Failure to meet the RPS goals may result in a fine, or the PUC may choose to provide an exemption or other administrative actions.
Although Colorado has significant installed solar capacity (Solar, 2017), wind energy dominates the renewable market in the state. As of 2016, 17.3\% of the electricity produced in Colorado came from wind energy (Wind, 2017). Innovations in technology and decreased manufacturing costs have made both wind and solar resources cost-competitive in Colorado, and wind energy is now the least-cost resource for utilities building new electric generation (Colorado Energy Office, 2016).

Colorado has two investor-owned utilities: Public Service Company of Colorado, known as Xcel Energy and centered in Denver, and Black Hills Energy, centered in Pueblo. Xcel Energy is by far the largest utility in the state, servicing more than half of Colorado's population, while Black Hills Energy services just under $10 \%$. The remainder of Colorado residents is serviced by 29 municipal and 22 cooperative electric utilities (Colorado Energy Office, 2017). Utility interests often reflect a combination of business and customer interests, which together impact their support for or opposition to the RPS. While Xcel has embraced the RPS, exceeded its goals, and even pushed for increased requirements in recent years, many smaller utilities have struggled to meet the goals and have opposed further increases to the RPS.

Despite these differences, we were told by stakeholders that Colorado's electric sector has a history of coming together to solve energy problems. In the 1980s, Colorado lacked diverse energy investments-instead they had "Coors, carbon, and the Cold War"-and were badly affected by the collapse of the energy market. As one interviewee noted, "the oil bust was really the tipping point that transformed how we work together...stakeholders came together to fix the economy because they knew that none of them could be successful in a broken economy."

\section{Nevada}

In 1997, Nevada became the third state to adopt an RPS (after Iowa in 1983 and New Jersey in 1991) and has since modified it a number of times (State Renewable Portfolio Standards and Goals, 2017). Nevada's RPS requires all electric utilities to generate or acquire a total of $25 \%$ of their electricity from renewable resources by 2025 , with incremental increases every two years until that date. Renewable energy credits can be purchased from independent power generators both within and outside of the state to help meet RPS requirements (Renewable Portfolio Standard, 2017), which has been a source of concern for many renewable energy advocates. Compliance with the RPS is reported annually to Nevada's PUC; like Colorado, failure to meet the RPS goals may result in a fine, or the PUC may choose to provide an exemption or other administrative actions (Renewable Portfolio Standard, 2017). Nevada's predominant renewable energy resource is solar; the RPS requires that $6 \%$ of electricity must come from solar energy resources by 2025 . While the state also has significant geothermal and wind resources, we heard from stakeholders in Nevada that wind is primarily available in the high elevations of the Sierra Nevada Mountains, which are highly inaccessible, expensive to develop, far from population centers, and comprise numerous protected areas.

At the time interviews were conducted for this study in 2016, Nevada's electric sector was deregulated and more than $90 \%$ of the state's population was serviced by a single investor-owned 
utility - NV Energy, which is the holding company of Nevada Power Company and Sierra Pacific Power. A handful of cooperative and municipalities together service the remaining $10 \%$. Because NV Energy is the only investor-owned utility and by far the largest utility in the state, it has had significant negotiating power when it comes to state energy policies, the RPS included.

Over the past 2 years, Nevada's electric sector has been rife with conflict and uncertainty, especially with regard to solar energy and utility regulation. In December 2015, at the urging of NV Energy and some of the electricity consumer base, the PUC ended net metering in the state on the grounds that nonsolar customers subsidizing solar customers. Specifically, these groups argued that non-solar customers were effectively paying for the infrastructure for solar power distribution, while solar panel owners paid a smaller share of these infrastructure costs due to net metering credits. Solar customers and renewable energy advocates were outraged by this decision, in part because it did not grandfather in existing solar customers. Governor Sandoval, a Republican, expressed discontent over the decision and re-instated a task force to advise him on possible means of addressing the issue.

In November 2016, Nevada voters passed the Energy Choice Initiative, a proposed constitutional amendment that would allow electricity users to choose a retail electricity supplier and generate electricity for themselves, effectively ending the monopoly held by NV Energy and deregulating the state's electric sector. Proponents of the measure were large-scale electricity users, environmental advocacy groups, and the solar industry. To become law and take effect in 2023, the proposed amendment will need a second round of approval by voters in 2018. In the spring of 2017, a number of energy-related measures were passed be the legislature, one of which reinstated net metering. A bill that would have raised the RPS requirements to $40 \%$ by 2030 and created a carveout for energy storage was vetoed by Governor Sandoval, who cited uncertainty in the impacts of electric-sector restructuring on the RPS as his reason for opposing the increase.

\section{Opportunities for Participation}

When asked about opportunities and incentives for participation in RPS implementation, interviewees discussed a wide range of formal and informal mechanisms aimed at utility customers (focus groups, public meetings) and/or expert stakeholder groups (informal discussions, legal proceedings, working groups); many also discussed how they participate in legislative processes, such as by creating ballot measures, talking with elected officials, or participating in taskforces to develop policy recommendations. Each of these processes is described in Table 1, including who participates, when they participate, and why they participate (i.e., the incentives or perceived advantages of the process); then, we summarize key examples and evidence discussed during interviews.

\section{Opportunities for Utility Customers, Citizens, and Interest Groups}

\section{Focus Groups}

Focus groups organized by utilities in Colorado were identified as one of the few opportunities for stakeholders to voice opinions about RPS programs directly to utilities. However, focus groups were also perceived as superficial efforts at engagement; for example, one interviewee from Colorado said "the utilities try to justify their plans by doing focus groups," but they are "statistically invalid" because they are conducted internally and the utility selects all of the participants. Stakeholders in both the states suggested that more focus groups were needed, but that utilities could better gauge public opinion on renewable energy if focus groups included better public representation and greater transparency.

\section{Public Meetings}

We heard from stakeholders in both the states that public meetings are a rare opportunity for lay stakeholders (i.e., the general public) to voice opinions directly to PUCs. Although meetings are difficult for some stakeholders to attend, it was noted by one interviewee in Colorado that some public meetings are webcast so stakeholders unable to participate can watch and that the PUC "tends to spread meetings all over" when possible to be more inclusive, particularly when they plan to discuss controversial issues such as rate changes.

However, there is no requirement that the PUCs either acknowledge or respond to public comments, and interviewees reported that PUCs typically do neither. Most interviewees perceived public meetings as superficial and used only to fulfill the requirements of the states' Open Meeting Laws. One stakeholder from Nevada said, "The PUC has no real interest in the process, they only do it to keep the public at bay." Another said that public meetings are "all a show. They thank people for coming, take their comments, people leave, and then the agency does whatever they wanted to do originally."

\section{Opportunities for Select Stakeholder Groups Informal Discussions}

Informal discussions were perceived by some interviewees as the most effective way to achieve organizational goals. As one interviewee in Colorado told us, "a lot can be done without litigation" but, she added, "there are many legal limitations" to what extent they can do. However, even during informal discussions, power remains with the utilities. For example, in Nevada one stakeholder group said that they often work with utilities to develop programs that help achieve RPS goals. But, rather than co-producing a plan, "the utility drafts the plan, then asks for feedback," and retains final decision-making power.

\section{Legal Proceedings}

Interviewees agreed that intervening in legal proceedings is meaningful and critical to impacting decisions about utility plans; for example, an interviewee in Colorado said that the PUC listens to all of the evidence and tries to make a balanced decision. Another interviewee said that if a consensus agreement is reached during settlement discussions among stakeholders, the PUC is likely to support the agreement. An interviewee from an environmental advocacy group in Colorado pointed out that the PUC must make rulings based only on evidence presented. As a result, environmental advocates must present evidence if they want to influence decisions. However, public comments-which are not legal evidence-cannot directly influence rulings. 
TABLE 1 | Mechanisms and incentives for stakeholders' participation in RPS policy implementation.

\begin{tabular}{|c|c|c|c|c|c|}
\hline & \multirow[b]{2}{*}{ Description } & \multirow[b]{2}{*}{ Who participates? } & \multirow[b]{2}{*}{$\begin{array}{l}\text { When do they } \\
\text { participate? }\end{array}$} & \multicolumn{2}{|c|}{ Stakeholders' perceptions of the process: } \\
\hline & & & & $\begin{array}{l}\text { Incentives for/benefits of } \\
\text { participation }\end{array}$ & $\begin{array}{l}\text { Disincentives for/drawbacks to } \\
\text { participation }\end{array}$ \\
\hline $\begin{array}{l}\text { Focus } \\
\text { Groups }\end{array}$ & $\begin{array}{l}\text { Small group of utility } \\
\text { customers convened by } \\
\text { utility to share opinions } \\
\text { about programs }\end{array}$ & $\begin{array}{l}\text { Restricted: utility } \\
\text { customers invited to } \\
\text { participate }\end{array}$ & $\begin{array}{l}\text { Late stages of program } \\
\text { design; occasionally } \\
\text { program approval process }\end{array}$ & $\begin{array}{l}\text { - Voice opinions directly to utility } \\
\text { - Develop mutual understanding }\end{array}$ & $\begin{array}{l}\text { - Little/no impact on decisions } \\
\text { - Limited dialog } \\
\text { - Poor transparency of results }\end{array}$ \\
\hline $\begin{array}{l}\text { Public } \\
\text { Meetings }\end{array}$ & $\begin{array}{l}\text { Meetings organized by } \\
\text { PUC to deliberate or take } \\
\text { action on items requiring } \\
\text { regulatory approval }\end{array}$ & Open & $\begin{array}{l}\text { Late stages of program } \\
\text { design }\end{array}$ & $\begin{array}{l}\text { - Direct contact between lay } \\
\text { stakeholders and decision makers } \\
\text { - Potential for learning and } \\
\text { development of mutual } \\
\text { understanding (dependent on if } \\
\text { participants are allowed to speak) }\end{array}$ & $\begin{array}{l}\text { - Little/no impact on decisions -May } \\
\text { be difficult to attend because of } \\
\text { time or location } \\
\text { - No opportunity for dialog } \\
\text { - } \text { Participation limited in terms of } \\
\text { whether participants can speak } \\
\text { (CO) or how long they can speak } \\
\text { (3 minutes in NV) } \\
\text { - Dominated by the PUC and utilities }\end{array}$ \\
\hline $\begin{array}{l}\text { Informal } \\
\text { Discussions }\end{array}$ & $\begin{array}{l}\text { Ad hoc, informal } \\
\text { conversations among } \\
\text { stakeholders and decision } \\
\text { makers }\end{array}$ & Open & $\begin{array}{l}\text { Late stages of program } \\
\text { design; program approval } \\
\text { process; implementation }\end{array}$ & $\begin{array}{l}\text { - Likely to impact decisions } \\
\text { - No time restrictions or formal } \\
\text { procedures to follow } \\
\text { - Build/strengthen relationships }\end{array}$ & $\begin{array}{l}\text { - Power asymmetries between } \\
\text { stakeholders and decision makers } \\
\text { - Requires existing relationships } \\
\text { be in place (in practice limits } \\
\text { participation to those already } \\
\text { involved) }\end{array}$ \\
\hline $\begin{array}{l}\text { Legal } \\
\text { Proceedings }\end{array}$ & $\begin{array}{l}\text { Legal process required } \\
\text { when utilities seek } \\
\text { regulatory approval for } \\
\text { rate changes or to take } \\
\text { major actions; PUC } \\
\text { makes a ruling based on } \\
\text { the written testimony of } \\
\text { the utility and all } \\
\text { intervening parties }\end{array}$ & $\begin{array}{l}\text { Restricted to } \\
\text { "intervening parties" } \\
\text { (Intervention requires } \\
\text { demonstration of a } \\
\text { stake in the case and } \\
\text { that interests are not } \\
\text { already represented) }\end{array}$ & Approval process & $\begin{array}{l}\text { - Likely to impact decisions } \\
\text { - May include sub-processes (public } \\
\text { workshops, informational } \\
\text { meetings, technical workshops) } \\
\text { that facilitate learning, build } \\
\text { social capital, and speed up } \\
\text { decision-making } \\
\text { - Structured, formal process allows } \\
\text { participants to know what to } \\
\text { expect }\end{array}$ & $\begin{array}{l}\text { - Time and resource-intensive } \\
\text { - May be difficult/intimidating to } \\
\text { navigate the process } \\
\text { - Legal representation is required, } \\
\text { but qualified attorneys and } \\
\text { witnesses may be lacking (NV), or } \\
\text { may have conflicts of interest (CO) } \\
\text { - Case transcripts are technical and } \\
\text { complex and must be purchased, } \\
\text { inhibiting transparency } \\
\text { - Not all interests equally } \\
\text { represented }\end{array}$ \\
\hline $\begin{array}{l}\text { Working } \\
\text { Groups }\end{array}$ & $\begin{array}{l}\text { Convened by PUC-often } \\
\text { in response to conflict } \\
\text { during a proceeding - to } \\
\text { address utility plans and } \\
\text { develop recommendations } \\
\text { for revision }\end{array}$ & $\begin{array}{l}\text { Restricted to } \\
\text { intervening parties in } \\
\text { legal proceeding; may } \\
\text { be exclusive to certain } \\
\text { parties }\end{array}$ & $\begin{array}{l}\text { Late stages of program } \\
\text { design; approval process }\end{array}$ & $\begin{array}{l}\text { - Likely to impact decisions } \\
\text { - Develops mutual understanding } \\
\text { - Facilitates learning } \\
\text { - Builds social capital } \\
\text { - May lead to consensus decision }\end{array}$ & $\begin{array}{l}\text { - Time and resource-intensive } \\
\text { - Power stays with decision maker } \\
\quad \text { (utility) }\end{array}$ \\
\hline $\begin{array}{l}\text { Legislative } \\
\text { Processes }\end{array}$ & $\begin{array}{l}\text { Processes that aim to } \\
\text { influence policy decisions } \\
\text { (e.g., talking with elected } \\
\text { officials, developing ballot } \\
\text { measures, or participating } \\
\text { in a taskforce, such as } \\
\text { the New Energy Industry } \\
\text { Taskforce in Nevada) }\end{array}$ & $\begin{array}{l}\text { Depends on the } \\
\text { process (e.g. Taskforce } \\
\text { members must be } \\
\text { invited; informal } \\
\text { discussions and ballot } \\
\text { measures open to all } \\
\text { stakeholders) }\end{array}$ & Policy design/adoption & $\begin{aligned} \text { - } & \text { Likely to impact policy decisions } \\
\text { - } & \text { More cost-effective than } \\
& \text { participating in implementation } \\
& \text { processes } \\
\text { - } & \text { Builds social capital } \\
\text { - } & \text { Stakeholders can initiate actions }\end{aligned}$ & $\begin{array}{l}\text { - May be difficult to navigate and } \\
\text { initiate discussions } \\
\text { - May be inaccessible to lay } \\
\text { stakeholders } \\
\text { - May be time and resource } \\
\text { intensive (e.g,. Taskforce } \\
\text { participation) }\end{array}$ \\
\hline
\end{tabular}

The formalities of proceedings, however, can be cost- and time-prohibitive to some stakeholders. Intervening parties are required to have legal representation, which is costly, particularly given that some cases can last months or years, and there may be a dozen new cases in a month.

Sub-processes of legal proceedings, including public workshops, informational meetings, and technical workshops were perceived by interviewees from Colorado as helpful in overcoming knowledge barriers associated with technically complex cases.

However, many interviewees perceived that not all interests were equally represented in legal proceedings. One interviewee from Nevada - a private citizen - said that the public in Nevada "is not really considered a stakeholder" and that "if they want to give their input, it has to be through the Bureau of Consumer Protection, which is severely understaffed."

\section{Working Groups}

When the PUC convenes a working group, it is often in response to conflicting perspectives before or during a legal proceeding. For example, an interviewee from Colorado said that sometimes a working group is convened because there is so much conflict that the PUC is unable to make a balanced decision. Working groups 
allow participants to build relationships, engage in dialog over multiple sessions, develop mutual understanding, and develop consensus decisions. Another interviewee from Colorado said that working groups are most effective when participants share power equally but that utility representatives tend to lead the working groups, deciding meeting times and agendas, and so hold more power than other participants.

\section{Participation in Legislative vs. Implementation Processes}

Particularly for organizations that cannot afford or do not have the expertise to intervene in legal proceedings, working with legislators was perceived by some interviewees as more effective than attending public meetings or other forums, but may be a last resort. For example, in 2016 in Nevada, some members of the public, frustrated by the PUC's decision regarding net metering, created a ballot measure to change the policy. Also in response to the PUC's decision, Nevada's Governor reinstated the New Energy Industry Taskforce to provide policy recommendations on how to promote the development of renewable energy and distributed energy resources in Nevada. Although the New Energy Industry Taskforce has no decision-making authority, Taskforce members we spoke with perceived that the Governor valued and intended to use their policy recommendations.

Much as stakeholders may participate in multiple types of participatory processes, participation in legislative and implementation processes are not mutually exclusive. For example, one group said they go to City Counsel and PUC workshops every month and send letters to legislators and the PUC in the hopes of spurring action to reduce energy load in southern Colorado. One group member described their participation as "energy whack-amole," where the game and people are changing so rapidly that by the time they understand what's going on, things have changed again. "It's tough to track all the information and keep up," he said, and added that "we can't be policy makers, but we can influence the policy makers by mobilizing the community," which is why much of their work involves educating people on electric-sector and renewable energy issues in their area.

\section{Factors That Shape Stakeholder Incentives to Participate}

Taken together, the participatory mechanisms offer a wide range of opportunities of varying levels of intensities. The literature identifies a number of potential incentives for participation, including enhanced ability of stakeholders to hold decision makers accountable, improved decisions, and process-related benefits. Interviewees perceived that some, but not all, avenues for participation produced these benefits. A few examples help to illustrate this point. First, legal proceedings were seen as a useful way to hold decision makers accountable, because the formality requires decision makers to record all evidence presented and provide a justification for the decision. Second, participation in more intensive activities, such as working groups and legal proceedings, was perceived as more likely to impact decisions about renewable energy and the RPS; although we did not measure the quality of decisions, there is strong evidence from the literature that decisions are often improved when stakeholders participate in decision-making. And third, many processes create opportunities for learning and developing social capital and mutual understanding, but these tend to be more intensive processes in which the same "repeat players" continue to interact over time.

As expected based on the literature, stakeholders felt the most incentivized to participate in processes that they perceived as meaningful and cost-effective, and in those that allowed learning, building of social capital, and development of mutual understanding. Interviewees said they were less likely to participate in processes that they perceived as superficial, costly, and that offered no opportunity for dialog or follow-up from decision makers. Although the literature suggests monetary costs can be a strong disincentive, we heard from interviewees that this acted more as an outright barrier. For example, given the high cost of participating in legal proceedings, many stakeholder groups simply cannot afford to participate. In response, some stakeholder groups in each state partnered with one another such that one group focused on implementation processes and the other on legislative actions.

However, in looking at the suite of participatory mechanisms, three qualities that may limit effectiveness or discourage participation appear common to many or all mechanisms: first, each puts stakeholders in a reactive position to utility-designed plans; second, in each process decision makers (utilities or PUCs) retain decision-making power; and third, very few of the processes were perceived by stakeholders to be meaningful.

\section{Participation Is Reactive}

Nearly all of the stakeholders we talked with described the reactive nature of their participation; that is, interviewees said that they tended to be involved somewhat late in the decisionmaking process, when plans and programs had already been written (Figure 1). This finding is consistent with the findings of Cotton and Devine-Wright (2012), and suggests a limited ability of stakeholders to impact decisions in such cases (Rowe and Frewer, 2000). For example, in the case of legal proceedings, utilities initiate the process by submitting plans for meeting RPS requirements. Interveners may then respond to the proposal with written testimony. We did not hear of any instances where utility plans were co-produced with other stakeholder groups.

\section{Decision Makers Retain Power}

Interviewees also noted that utilities and PUCs retain decisionmaking power in all engagement processes, many of which also lacked transparency. For example, stakeholders may comment on proposed actions during public meetings, but the PUC chooses whether to incorporate their comments in the final decision. Again, this is consistent with prior findings that public meetings, although meant to foster transparency and accountability, tend to be superficial (Kelshaw, 2006), and may be perceived by decision makers as an easy means of fulfilling legal requirements, thus giving a false appearance of public involvement (Fiorino, 1990). With the exception of legal proceedings in which interveners' comments are recorded as evidence, there are no requirements that the PUC respond to stakeholder concerns in any of the other processes mentioned during interviews. Although limited 


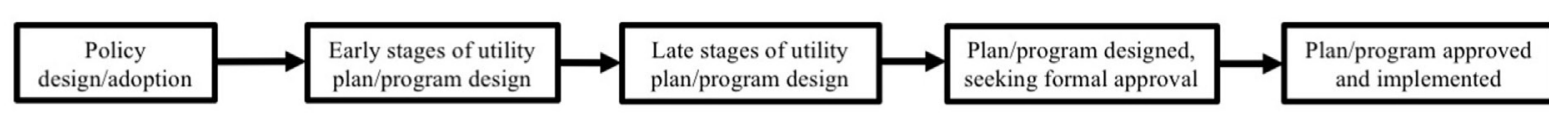

Focus groups

Focus groups

Legislative

actions/policy

development
Public meetings

Informal discussion

Working group

Legal proceeding

FIGURE 1 | Stages in the decision-making process during which stakeholders participate through a variety of mechanisms.

transparency of participatory process outcomes is common to processes like focus groups (Rowe and Frewer, 2000), we heard that transparency was lacking in nearly all processes, which hinders learning and the ability of participants to hold decision makers accountable.

\section{Meaningful Participation Is Limited to Expert Stakeholders}

Finally, meaningful participation appears limited to expert stakeholder groups with existing ties to decision makers and formal processes. Even expert stakeholders' ability to influence decisions may be limited, as they tend to be involved late in decision-making when utility plans have already been designed. According to some scholars (Holmes, 2011), true participation requires that stakeholders are able to influence decisions; by this standard, only legal proceedings qualify as true participation, and even then, not all stakeholder groups are equally able to influence decisions.

A number of interviewees noted that lay stakeholdersmembers of the public and utility customers-are limited to participating in less-intensive processes, most often public meetings. Therefore, they have very little opportunity to influence decisions or derive other process-related outcomes, such as learning or building social capital. For example, one member of the public from Nevada told us he feels excluded from processes that allow repeated interaction and dialog with other stakeholders and that he "doesn't have a real relationship with any other group. They have different interests, and every group seems to have a one-track mind." Similarly, in Colorado, stakeholders from a community advocacy group said that, although they regularly attend PUC workshops and meetings, send letters, and make calls to legislators, they have found it difficult to build relationships with other stakeholder groups. As Ansell and Gash (2008) pointed out that, when stakeholders hold opposing interests, they may find that none can achieve their goals without working together; indeed, the stakeholders from each state who were unable to work with other groups expressed greater frustration with decision makers, and reported less ability to achieve their goals than stakeholders who had strong relationships with other groups. Because individuals and groups may be less inclined to participate in future activities when they have felt discouraged by past efforts, the consequences of this may extend beyond current planning efforts (Irvin and Stansbury, 2004).

\section{DISCUSSION}

In this study, we ask how and why stakeholders participate in decision-making related to RPS policy implementation. Three important findings emerge from our interview analysis. First, we find that stakeholders may play a long game, participating in the short term to build coalitions, relationships with decision makers, and knowledge that will eventually allow them to influence decisions later on; second, stakeholders often participate in multiple types of processes to achieve goals; and third, the regulatory environment influences which participatory processes are available, the incentives for participation, and ultimately the outcomes of stakeholders' participation.

\section{Playing the Long Game}

Given that the literature identifies meaningful participation as a key incentive for stakeholders, it was surprising that stakeholders continued to participate in mechanisms that were widely viewed as superficial, providing little or no opportunity to influence policy decisions. One implication of this surprising finding is that stakeholders may tend to view their participation in different policy venues not as one-shot opportunities to influence immediate decisions, but rather as opportunities to position themselves as participants in long-term policy processes. Interviewees suggested that they derived benefits from participating, such as building relationships with decision makers and other stakeholders and enhancing knowledge, that would position them to influence decisions later on. Several interviewees also indicated that they were hopeful they might have greater influence as individual decision makers changed over time.

The idea that stakeholders may be seeking greater long-term political influence is bolstered by the fact that some stakeholder 
groups have formed coalitions to create policy change. For example, stakeholders from environmental advocacy groups in Colorado said that they work with other groups with similar goals. While one group may focus on influencing legislative agendas, other focuses on implementation processes. In doing so, they are each able to extend their resources further, potentially increasing their impacts on both policy and implementation decisions. These findings are consistent with the Advocacy Coalition Framework, which predicts that interest groups achieve goals over time by forming coalitions with other organizations around shared interests (Weible and Sabatier, 2007). Kelshaw (2006) argued that participation in any process, whether highly structured and formal or ad hoc and informal, is political in that it has potentially far-reaching consequences beyond impacting immediate decisions. Our findings suggest that stakeholders may participate in electric sector decision-making not only to impact immediate decisions but also to enact long-term political change. Moreover, since relationship building with other participants facilitates long-term political change, participation is about longterm relationship building as well as achievement of short-term policy objectives.

\section{Seeking Multiple Avenues for Participation}

Scholars of public participation often study participatory processes in isolation, seeking to understand how a particular participatory forum is used to shape decision making. However, our findings show that participatory processes do not work in isolation but rather in conjunction with one another, allowing participants to realize a broader range of benefits.

We find that many stakeholders-particularly expert stakeholder groups-participated in multiple formal and informal avenues of participation. For these stakeholders, participating in multiple types of processes was perceived as a way of increasing one's impact on decisions. For example, interviewees noted the unique benefits of participating in both formal processes, such as legal proceedings, and informal processes, such as informal discussions: whereas formal and highly structured processes allow participants to know what is expected and prepare accordingly, informal processes allow more casual interactions with fewer restrictions, and may be more effective at building social capital. This finding highlights the importance of relationship building among participants. Informal interactions may help participants find common ground with other groups who share similar interests. Informal interactions may also allow participants to understand the policy positions and interests of participants with opposing interests, providing participants with useful information about how to behave strategically in more formal settings.

While our findings highlight that multiple avenues for participation exist and can shape the participants and outcomes of other avenues within the same policy context, this in turn raises equity implications. Expert stakeholders and those who have wellestablished relationships with decision makers generally have far greater opportunities to participate in the full range of formal and informal mechanisms to shape policy. Thus, while the ability to strategically participate in multiple participation avenues may help make participation more meaningful for expert stakeholders, it may at the same time make participation less meaningful for ordinary citizens or groups who are less connected with decision makers.

\section{Participation as Part of a Broader Context}

Finally, our results suggest that agency culture and prior experience with stakeholders' engagement may influence which participatory processes are made available, how these are perceived by stakeholders, and the resulting outcomes; in other words, stakeholders' participation is complex and exists as part of a broader political context.

In both Colorado and Nevada, interviewees discussed how historical relationships with stakeholder groups, individual PUC Staff members, and PUC culture influence the agency's perceived value of stakeholder input in electric-sector decisionmaking. Perceived value of stakeholder input appears to be a key determinant of whether and how decision makers seek out and use stakeholder input in decisions. While interviewees from Colorado described the PUC as relatively receptive to stakeholder input, those from Nevada reported that the PUC had tried to limit participation as much as possible.

Stakeholders in both states suggested that past experiences with stakeholders' engagement has likely contributed to the current status of relationships between stakeholders and decision makers, which supports prior findings that a history of conflict or cooperation influences incentives to participate (Chess and Purcell, 1999). Whereas Colorado's electric sector has a strong history of cooperation among key interest groups beginning with the 1970s oil crisis, growing conflict in Nevada over net metering has damaged many stakeholders' trust in the PUC. Additionally, Nevada has one powerful investor-owned utility with close ties to the PUC, while Colorado's two large investor-owned utilities often have divergent interests, which may be one reason the Colorado PUC tends to consult expert stakeholder groups in an attempt to make balanced decisions. The role of past interactions in influencing stakeholder-decision maker relationships is not surprising, given previous findings that poorly conducted or unsuccessful stakeholders' engagement efforts can backfire and deter agencies from developing more effective engagement practices (Lukensmeyer et al., 2011; Nabatchi and Leighninger, 2015).

Many stakeholders in Colorado perceived that the PUC tries to make balanced decisions, taking into account all stakeholders' perspectives when possible. Additionally, many felt that participation had improved relationships and helped to build trust between decision makers and stakeholders. For example, one interviewee said that the PUC often encouraged stakeholders and utilities to work together to solve conflict outside of legal proceedings. Several interviewees also said that the PUC had become more receptive to input from stakeholder groups in recent years, which they attributed to the individual Commissioners and strengthened stakeholder-decision maker relationships resulting from repeated, positive interactions. As one interviewee put it, "the PUC views each stakeholder group as representing a specific slice of the public interest," and therefore the input from each group is valued. While these views were common, they were not unanimous. A minority of stakeholders felt excluded from participatory processes and had little trust in the PUC, showing how equity concerns about access to decision making can persist 
even in contexts where decision makers actively seek stakeholders' participation.

In Nevada, on the other hand, stakeholders widely perceived that the PUC has a negative attitude toward stakeholders' participation and that stakeholder input is neither valued nor used in decision-making. For example, one interviewee from Nevada said that "[the PUC] makes it as difficult as possible [to intervene]. The attitude is that they know best." We were told by two stakeholders that over the last decade, Nevada's PUC had attempted several times to exempt the agency from the state's open meeting law, arguing that they are a quasi-judicial agency and thus not directly accountable to the public. Furthermore, because the majority of PUC Staff stays with the agency for a long term and trains and advises incoming Commissioners, there is little cultural change within the organization over time. Therefore, the agency tends toward maintaining the status quo rather than supporting innovation and change.

Most stakeholders in both Colorado and Nevada indicated some level of mistrust of the PUC and utilities. However, rather than acting as a disincentive for participation, modest levels of mistrust may promote participation as stakeholders do not feel their interests will be represented unless they show up. One stakeholder in Colorado indicated that there are "cozy relationships between the regulators and the utilities" that allow the utilities to "weasel around the rules" regarding rate structures. An interviewee in Nevada said that, although there is a law in Nevada prohibiting communication between parties behind closed doors before the PUC makes a ruling, there are "rumors that the head of NV Energy meets regularly with the PUC for lunch" and may have a closer relationship than is appropriate. Another stakeholder suggested a similar level of mistrust, saying that "the utility is the wolf, the public is the sheep, and the regulator is supposed to be the sheepdog that protects the sheep from the wolf," hinting that this is not the case.

\section{CONCLUSION}

In this study, we ask how and why do these stakeholders participate in decision-making about how RPS policies are implemented? Prior studies on stakeholders' participation have tended to look at participatory mechanisms in isolation; however, the long-term and iterative nature of renewable energy policy implementation and the wide range of stakeholders involved in decision-making suggest the need of a broader examination of participation. Here, we look at the suite of participatory opportunities available and how stakeholders choose which to engage in. Our interviews with stakeholders in Colorado and Nevada reveal a range of mechanisms, some available to all stakeholder groups (focus groups, public meetings) and some limited to select stakeholder groups (informal discussions, working groups, legal proceedings).

Furthermore, the literature on stakeholders' participation tends to treat all participants the same; however, the ability to influence decisions may be quite different for different participants depending on the stakeholder. We find that meaningful participation may be limited to stakeholder groups that are highly knowledgeable about the issues, have the resources to engage in long-term and sustained participation, and have long-standing relationships with decision makers and other stakeholders. The limited opportunity for knowledge sharing and building of social capital in the mechanisms available to lay stakeholders further restricts their ability to meaningfully engage with decision makers and other stakeholders.

Although many stakeholders were skeptical about their ability to impact decisions, they were willing to participate as a means of building coalitions and relationships with other stakeholder groups and were hopeful that long-term participation would eventually influence decision makers, particularly as agency culture, relationships, and individual decision makers change over time. Finally, we find that the types of mechanism and the way they are carried out by agencies are affected by agency culture, experiences with past engagement efforts, and historical relationships, which together impact the incentives for stakeholders to participate and outcomes.

As electricity generation is increasingly shifting toward smallscale, renewable resources such as wind and solar, its governance is becoming more complex involving a wider range of policies and actors. State-level renewable energy policies-namely the Renewable Portfolio Standard-require utilities to design and carry out programs to meet renewable energy goals, and in doing so shape whether, when, and how RPSs are implemented, and the extent to which RPS goals are achieved. Stakeholders therefore have a potentially important role in shaping decisions about how to carry out complex policies like the RPS; and yet, we find that opportunities to influence decisions are limited to select stakeholder groups through mechanisms that maintain existing power imbalances and lack transparency, thereby restricting potential benefits gained from participation. We suggest that the scholarship on participation in policy processes could be enhanced with greater attention to find how the long-term interactions between regulatory context, participatory processes, incentives, and participants shape policy outcomes.

\section{ETHICS STATEMENT}

This study was carried out in accordance with the recommendations of the IRB Committee at the University of Arizona with written informed consent from all subjects. All subjects gave written informed consent in accordance with the Declaration of Helsinki. The protocol was approved by the IRB Committee at the University of Arizona.

\section{AUTHOR CONTRIBUTIONS}

Both authors conceived of the idea, developed the methods of data collection, and conducted interviews. VR performed interview data analysis. Both authors discussed the results and contributed to the final manuscript.

\section{FUNDING}

Funding for this study was provided by the University of Arizona's: Institute of the Environment; Office of Research, Discovery, and Innovation; Social and Behavioral Sciences Research Institute; and Graduate Interdisciplinary Program. 


\section{REFERENCES}

Adams, B. (2004). Public meetings and the democratic process. Public Adm. Rev. 64, 43-54. doi:10.1111/j.1540-6210.2004.00345.x

Ansell, C., and Gash, A. (2008). Collaborative governance in theory and practice. J. Public Adm. Res. Theory 18, 543-571. doi:10.1093/jopart/mum032

Arnstein, S. R. (1969). A ladder of citizen participation. J. Am. Inst. Plann. 35, 216-224. doi:10.1080/01944366908977225

Bakke, G. (2016). The Grid: The Fraying Wires Between Americans and Our Energy Future. New York, NY: Bloomsburry Publishing.

Baldwin, E., Rountree, V., and Jock, J. (2018). Distributed resources and distributed governance: stakeholder participation in demand side management governance. Energy Res. Soc. Sci. 39, 37-45. doi:10.1016/j.erss.2017.10.013

Beierle, T. C. (2002). The quality of stakeholder-based decisions. Risk Anal. 22, 739-749. doi:10.1111/0272-4332.00065

Beierle, T. C., and Konisky, D. M. (2000). Values, conflict, and trust in participatory environmental planning. JPolicy Anal. Manage. 19, 587-602. doi:10.1002/1520-6688(200023)19:4<587::AID-PAM4>3.0.CO;2-Q

Berry, T., and Jaccard, M. (2001). The renewable portfolio standard: design considerations and an implementation survey. Energy Policy 29, 263-277. doi:10.1016/ S0301-4215(00)00126-9

Blackstock, K. L., Kelly, G. J., and Horsey, B. L. (2007). Developing and applying a framework to evaluate participatory research for sustainability. Ecol. Econ. 60, 726-742. doi:10.1016/j.ecolecon.2006.05.014

Bojórquez-Tapia,L.A.,delaCueva,H.,Díaz,S.,Melgarejo,D.,Alcantar,G.,Solares,M.J., et al. (2004). Environmental conflicts and nature reserves: redesigning Sierra San Pedro Mártir National Park, Mexico. Biol. Conserv. 117, 111-126. doi:10.1016/S0006-3207(03)00265-9

Boyte, H. C. (2011). Constructive politics as public work: organizing the literature. Polit. Theory 39, 630-660. doi:10.1177/0090591711413747

Bradford, N. (1998). Prospects for associative governance: lessons from Ontario, Canada. Pol. Soc. 26, 539-573. doi:10.1177/0032329298026004005

Brown, A. J. (2002). Collaborative governance versus constitutional politics: decision rules for sustainability from Australia's South East Queensland forest agreement. Environ. Sci. Policy 5, 19-32. doi:10.1016/S1462-9011(02)00022-9

Bryson, J. M., Quick, K. S., Slotterback, C. S., and Crosby, B. C. (2013). Designing public participation processes. Public Adm. Rev. 73, 23-34. doi:10.1111/j.1540-6210.2012.02678.x

Burroughs, R. (1999). When stakeholders choose: process, knowledge, and motivation in water quality decisions. Soc. Nat. Resour. 12, 797-809. doi:10.1080/089419299279326

Burton, P., Goodlad, R., Croft, J., Abbott, J., Hastings, A., Macdonald, G., et al. (2004). What works in community involvement in area-based initiatives? A systematic review of the literature. Home Off. Online Rep. 53, 4.

Chess, C., and Purcell, K. (1999). Public participation and the environment: do we know what works? Environ. Sci. Technol. 33, 2685-2692. doi:10.1021/es980500g

Cogan, A., and Sharpe, S. (1986). Planning Analysis: The Theory of Citizen Involvement. University of Oregon. Available from: http://pages.uoregon.edu/ rgp/PPPM613/class10theory.htm

Colorado Energy Office. (2016). Annual Report. Available from: https://www. colorado.gov/pacific/sites/default/files/atoms/files/Colorado\%20Energy\%20 Office\%20Annual\%20Report\%202015-2016.pdf

Colorado Energy Office. (2017). Electric Utilities. Available from: https://www. colorado.gov/pacific/energyoffice/electric-utilities

Cotton, M., and Devine-Wright, P. (2012). Making electricity networks "visible": industry actor representations of "publics" and public engagement in infrastructure planning. Public Underst. Sci. 21, 17-35. doi:10.1177/0963662510362658

Crow, D. A., Albright, E. A., and Koebele, E. (2016). Environmental rulemaking across states: process, procedural access, and regulatory influence. Environ. Plann. C Gov. Policy 34, 1222-1240.

Dasgupta, A., and Beard, V. A. (2007). Community driven development, collective action and elite capture in Indonesia. Dev. Change 38, 229-249. doi:10.1111/j. 1467-7660.2007.00410.x

DeSario, J., and Langton, S. (1987). Citizen Participation in Public Decision Making. Westport: Greenwood Press.

Durkay, J. (2017). State Renewable Portfolio Standards and Goals. National Conference of State Legislatures. Available from: http://www.ncsl.org/research/ energy/renewable-portfolio-standards.aspx
Dyer, J., Stringer, L. C., Dougill, A. J., Leventon, J., Nshimbi, M., Chama, F., et al. (2014). Assessing participatory practices in community-based natural resource management: experiences in community engagement from southern Africa. J. Environ. Manage. 137, 137-145. doi:10.1016/j.jenvman.2013.11.057

Endres, D. (2009). Science and public participation: an analysis of public scientific argument in the Yucca Mountain controversy. Environ. Commun. 3, 49-75. doi:10.1080/17524030802704369

Energy Information Administration (EIA). (2017). Electricity in the U.S. Available from:https://www.eia.gov/energyexplained/index.cfm?page=electricity_ in_the_united_states

European Institute for Public Participation (EIPP). (2009). Public Participation in Europe: An International Perspective. Available from: http://www.partizipation.at/fileadmin/media_data/Downloads/Zukunftsdiskurse-Studien/ pp_in_e_report_03_06.pdf

Feldman, M. S., and Quick, K. S. (2009). Generating resources and energizing frameworks through inclusive public management. Int. Public Manage. J. 12, 137-171. doi:10.1080/10967490902873408

Fiorino, D. (1990). Citizen participation and environmental risk: a survey of institutional mechanisms. Sci. Technol. Hum. Values 15, 226-243. doi:10.1177/016224399001500204

Fleischmann, D. (2016). Renewable Energy Was 16.9 Percent of US Electric Generation in the First Half of 2016. Renewable Energy World. Available from: http://www.renewableenergyworld.com/articles/2016/08/renewable-energywas-16-9-percent-of-u-s-electric-generation-in-the-first-half-of-2016.html

Freeman, R. E., and Reed, D. L. (1983). Stockholders and stakeholders: a new perspective on corporate governance. Calif. Manage. Rev. 25, 88-106. doi:10.2307/ 41165018

Fung, A. (2006). Varieties of participation in complex governance. Public Adm. Rev. 66, 66-75. doi:10.1111/j.1540-6210.2006.00667.x

Fung, A. (2007). Democratic theory and political science: a pragmatic method of constructive engagement. Am. Polit. Sci. Rev. 101, 443-458. doi:10.1017/ S000305540707030X

Futrell, R. (2003). Technical adversarialism and participatory collaboration in the US chemical weapons disposal program. Sci. Technol. Hum. Values 28, 451-482. doi:10.1177/0162243903252762

Geoghegan, T., and Renard, Y. (2002). Beyond community involvement: lessons from the insular Caribbean. Parks 12, 16-27.

Gormley, W. T. Jr. (1983). The Politics of Public Utility Regulation. Pittsburgh, PA: University of Pittsburgh Press.

Holmes, B. (2011). Citizens' Engagement in Policymaking and the Design of Public Services. Parliamentary Library. Available at: http://observgo.uquebec.ca/ observgo/fichiers/31648_Australie.pdf

Irvin, R. A., and Stansbury, J. (2004). Citizen participation in decision making: is it worth the effort? Public Adm. Rev. 64, 55-65. doi:10.1111/j.1540-6210. 2004.00346.x

Kelshaw, T. (2006). "Communication as political participation," in Communication As... Perspectives on Theory (Thousand Oaks, CA: Sage Publishing), 155-163.

Koontz, T. M., and Thomas, C. W. (2006). What do we know and need to know about the environmental outcomes of collaborative management? Public Adm. Rev. 66, 111-121. doi:10.1111/j.1540-6210.2006.00671.x

Lee, C. W. (2014). Walking the talk: the performance of authenticity in public engagement work. Sociol. Q. 55, 493-513. doi:10.1111/tsq.12066

Lee, C. W., McQuarrie, M., and Walker, E. T. (eds) (2015). Democratizing Inequalities: Dilemmas of the New Public Participation. New York, NY: NYU Press.

Levine, P., Fung, A., and Gastil, J. (2005). Future directions for public deliberation. J. Public Deliber. 1, 1-13.

Lifsher, M. (2015). Drinks, Dinners, Favors Helped PGङE Lobbyist Build PUC Ties, Emails Show. Available from: http://www.latimes.com/business/la-fipuc-cherry-emails-20150422-story.html

Lukensmeyer, C. J., Goldman, J., and Stern, D. (2011). Assessing Public Participation in an Open Government Era. IBM Center for the Business of Government. Available at: http://www.govexec.com/pdfs/082211jm1.pdf

Lutsey, N., and Sperling, D. (2008). America’s bottom-up climate change mitigation policy. Energy Policy 36, 673-685. doi:10.1016/j.enpol.2007.10.018

Macnaghten, P., and Jacobs, M. (1997). Public identification with sustainable development: investigating cultural barriers to participation. Global Environ. Change 7, 5-24. doi:10.1016/S0959-3780(96)00023-4 
Martin, J. (2009). Distributed vs. centralized electricity generation: are we witnessing a change of paradigm? An introduction to distributed generation. Available at: http://www.vernimmen.be/ftp/An_introduction_to_distributed_generation.pdf

Martin, J., Tett, L., and Kay, H. (1999). Developing collaborative partnerships: limits and possibilities for schools, parents and community education. Int. Stud. Sociol. Educ. 9, 59-75. doi:10.1080/09620219900200035

McGuire, M. (2006). Collaborative public management: assessing what we know and howweknowit.PublicAdm.Rev.66,33-43.doi:10.1111/j.1540-6210.2006.00664.x

Nabatchi, T. (2010). Addressing the citizenship and democratic deficits: the potential of deliberative democracy for public administration. Am. Rev. Public Adm. 40, 376-399. doi:10.1177/0275074009356467

Nabatchi, T., and Leighninger, M. (2015). Public Participation for 21st Century Democracy. Hoboken, NJ: John Wiley \& Sons.

Nelkin, D., and Pollak, M. (1979). Public-participation in technological decisions-reality or grand illusion. Technol. Rev. 81, 54-64.

Pearce, W. B., and Pearce, K. A. (2010). Aligning the Work of Government to Strengthen the Work of Citizens: A Study of Public Administrators in Local and Regional Government. Dayton, OH: Kettering Foundation Report.

Perhac, R. M. Jr. (1998). Defining risk: normative considerations. Hum. Ecol. Risk Assess. 2, 381-392. doi:10.1080/10807039609383615

Quick, K. S., and Bryson, J. M. (2016). "Theories of public participation in governance," in Handbook in Theories of Governance (Cheltenham: Edward Elgar Press).

Reed, M. S. (2008). Stakeholder participation for environmental management: a literature review. Biol. Conserv. 141, 2417-2431. doi:10.1016/j.biocon.2008.07.014

Renewable Energy Standard. (2017). Available from: https://www.colorado.gov/ pacific/energyoffice/renewable-energy-standard

Renewable Portfolio Standard. (2017). Available from: http://puc.nv.gov/ Renewable_Energy/Portfolio_Standard

Renn, O., Webler, T., Rakel, H., Dienel, P., and Johnson, B. (1993). Public participation in decision making: a three-step procedure. Policy Sci. 26, 189-214. doi:10.1007/BF00999716

Roberts, N. (2004). Public deliberation in an age of direct citizen participation. Am. Rev. Public Adm. 34, 315-353. doi:10.1177/0275074004269288

Rosenbloom, D. H. (1983). Public administrative theory and the separation of powers. Public Adm. Rev. 43, 219-227. doi:10.2307/976330

Rowe, G., and Frewer, L. (2000). Public participation methods: a framework for evaluation. Sci. Technol. Hum. Values 25, 3-29. doi:10.1177/016224390002500101

Schneider, M., Scholz, J., Lubell, M., Mindruta, D., and Edwardsen, M. (2003). Building consensual institutions: networks and the National Estuary Program. Am. J. Pol. Sci. 47, 143-158. doi:10.1111/1540-5907.00010

Scott, T. (2015). Does collaboration make any difference? Linking collaborative governance to environmental outcomes. J. Policy Anal. Manage. 34, 537-566. doi:10.1002/pam.21836

Simonsen, W., and Robbins, M. D. (2000). Citizen Participation in Resource Allocation. Boulder, CO: Westview Press.
Solar. (2017). Available from: https://www.colorado.gov/pacific/energyoffice/solar State Renewable Portfolio Standards and Goals. (2017). Available from: http:// www.ncsl.org/research/energy/renewable-portfolio-standards.aspx

Teitelbaum, S. (2014). Criteria and indicators for the assessment of community forestry outcomes: a comparative analysis from Canada. J. Environ. Manage. 132, 257-267. doi:10.1016/j.jenvman.2013.11.013

Tippett, J., Handley, J. F., and Ravetz, J. (2007). Meeting the challenges of sustainable development - a conceptual appraisal of a new methodology for participatory ecological planning. Prog. Plann. 67, 9-98. doi:10.1016/j.progress.2006. 12.004

Ulibarri, N. (2015). Collaboration in federal hydropower licensing: impacts on process, outputs, and outcomes. Public Perform. Manage. Rev. 38, 578-606. doi:10.1080/15309576.2015.1031004

Walker, G. B., and Daniels, S. E. (2001). Natural resource policy and the paradox of public involvement: bringing scientists and citizens together. J. Sustainable For. 13, 253-269. doi:10.1300/J091v13n01_05

Warner, J. F. (2006). More sustainable participation? Multi-stakeholder platforms for integrated catchment management. Int. J. Water Resour. Dev. 22, 15-35. doi:10.1080/07900620500404992

Weible, C. M., and Sabatier, P. A. (2007). "A guide to the advocacy coalition framework," in Handbook of Public Policy Analysis: Theory, Politics, and Methods (Boca Raton, FL: CRC Press), 123-136.

West, W. (2004). Formal procedures, informal processes, accountability, and responsiveness in bureaucratic policy making: an institutional policy analysis. Public Adm. Rev. 64, 66-71. doi:10.1111/j.1540-6210.2004.00347.x

Wiedemann, P. M., and Femers, S. (1993). Public participation in waste management decision making: analysis and management of conflicts. J. Hazard. Mater. 33, 355-368. doi:10.1016/0304-3894(93)85085-S

Wind. (2017). Available from: https://www.colorado.gov/pacific/energyoffice/ wind

Wondolleck, J. M., Manring, N. J., and Crowfoot, J. E. (1996). Teetering at the top of the ladder: the experience of citizen group participants in alternative dispute resolution processes. Sociol. Perspect. 39, 249-262. doi:10.2307/1389311

Wondolleck, J. M., and Yaffee, S. L. (2000). Making Collaboration Work: Lessons from Innovation in Natural Resource Managment. Washington, DC: Island Press.

Conflict of Interest Statement: The authors declare that the research was conducted in the absence of any commercial or financial relationships that could be construed as a potential conflict of interest.

Copyright (c) 2018 Rountree and Baldwin. This is an open-access article distributed under the terms of the Creative Commons Attribution License (CC BY). The use, distribution or reproduction in other forums is permitted, provided the original author(s) and the copyright owner are credited and that the original publication in this journal is cited, in accordance with accepted academic practice. No use, distribution or reproduction is permitted which does not comply with these terms. 